\title{
Association between family functionality and hypoglycemia in people with type 2 diabetes in primary care
}

\begin{abstract}
Introduction: Hypoglycemia is an acute complication of diabetes and is considered an endocrine emergency. It can cause permanent neurological damage and even death. A functional family may be able to prevent this type of complications in diabetic patients.

Objective: Determine the association between family functionality with hypoglycemia in people with type 2 diabetes in primary care.

Materials and methods: Cross-sectional study in 160 patients with type 2 diabetes, aged 30 to 90 years, who presented hypoglycemia and required hospital attention during October 2017 to August 2018. Family functionality and family life cycle was determined by the family APGAR (adaptation, association, growth, affection, resolution). Descriptive statistics and Chi square test were applied using the SPSS v.21 program.

Results: The frequency of hypoglycemia in the study population was $2.04 \% ; 85 \%$ of patients presented family dysfunction, an association was observed between family functionality and hypoglycemia (Chi-square $14.809, \mathrm{p}=0.022$ ).

Conclusion: There is an association between family functionality and hypoglycemia in diabetic patients. The care of diabetic patients should include their families and support networks, in order to reduce acute complications such as hypoglycemia
\end{abstract}

Keywords: hypoglycemia, diabetes mellitus, family relations, diabetic patients, glucose levels
Volume 3 Issue 3 - 2019

\author{
Lucila Barajas Rodríguez,' María Elena Haro \\ Acosta, ${ }^{2}$ Rebeca Esther Martínez Fierro, ${ }^{3}$ \\ Alberto Barreras Serrano, ${ }^{4}$ Joan Dautt Silva ${ }^{5}$ \\ 'Family Medicine, Family Medical Unit No. 16 of the Mexican \\ Institute of Social Security (IMSS), Mexico \\ ${ }^{2}$ DSc Pediatrician and Teacher in Universidad Autónoma de Baja \\ California in Baja California, México \\ ${ }^{3}$ Family Medicine, Family Medical Unit No.40 of the Mexican \\ Institute of Social Security (IMSS), Mexico \\ ${ }^{4}$ DSc in Universidad Autónoma de Baja California in Baja \\ California, México \\ ${ }^{5}$ Medical intern, General Hospital of Zone No 30 of IMSS, \\ Mexico
}

Correspondence: María Elena Haro Acosta, Dr. Humberto Torres Sangines Street, Department of Pediatrics, School of Medicine, Universidad Autónoma de Baja California, S/N. Centro Cívico, CP 21000, Mexicali, Mexico,

Email lenaharo@live.com.mx,elena.haro@uabc.edu.mx

Received: March 27, 2019 | Published: May 06, 2019

\section{Introduction}

Hypoglycemia is an acute complication of Diabetes Mellitus (DM); it is characterized by blood glucose levels $<70 \mathrm{mg} / \mathrm{dL} .{ }^{1}$ The clinical manifestations that it causes can lead to permanent neurological damage and even death. ${ }^{2}$ The risk factors for development hypoglycemia in diabetic patients are: meal delay or omission, excessive alcohol drinking, intense exercise without prior food intake or accidental drug dosage errors. ${ }^{3}$ Given its chronicity and complexity, diabetes care relies heavily on a functioning family system. It has been established that healthy family interactions can have a positive impact in health education and management in patients with chronic illnesses, such as diabetes. ${ }^{4-6}$ The family life cycle (FLC) is the sequence of phases that a family goes through since their establishment all the way to their dissolution; ${ }^{7}$ the World Health Organization has a model that consists of six stages of the FLC: formation, extension, completed extension, contraction, completed contraction and dissolution. ${ }^{8}$ This cycle is a dynamic process that involves the individual health of each family member; thus, it can determine the presence or absence of chronic degenerative diseases as result of individual and family lifestyles. ${ }^{9}$ Researchers have found that family involvement in the day-to-day management of diabetes was critical for its control..$^{10} \mathrm{~A}$ study made by Beltrán et al., ${ }^{11}$ related glycemic control with family functionality in type 2 diabetic patients, finding that there is a relationship between good glycemic control and functional families. Likewise, a Peruvian study evaluated whether knowledge about diabetes mellitus and family functionality are associated with therapeutic adherence in adults with type $2 \mathrm{DM}$; he observed that poor adherence to treatment is influenced by family dysfunction and poor knowledge about diabetes. ${ }^{12}$ As part of the management of hypoglycemia, family is considered an important pillar to support the patient, being that, if this type of support does not exist, it can favor a lack of metabolic control or, in fact, limit the treatment of the disease. ${ }^{6}$ There is little information between the relationship of hypoglycemia with family functionality, which are important for the patient to have good control of diabetes; therefore, the objective of the study was to determine the association between family functionality and hypoglycemia in patients with type 2 diabetes.

\section{Materials and methods}

A descriptive, analytical, cross-sectional and prospective study was conducted in patients aged 30 to 90 years with type 2 diabetes and hypoglycemia, who were treated in the emergency department of the Family Medicine Unit (FMU) No. 16 of the Mexican Institute of Social Security (IMSS, for its acronym in Spanish) in Mexicali, Baja California. Convenience sampling was used and we included patients who were attended from October 2017 to August 2018. The inclusion criteria were: diagnosis of type 2 diabetes, ages 30 to 90 years, medical attention given during the study period, agreement to participate in the study through written informed consent. Patients with terminal illnesses or that did not have contact with their family were excluded. Family functionality was assessed using the family APGAR questionnaire, ${ }^{13,14}$ which evaluates the perception of the patient regarding five elements: 1.- Adaptation (degree where a family member is satisfied with the help or support he receives); 2.- Participation (degree where decisions 
are shared or members' satisfaction regarding communication and problem solving); 3.- Development or growth (freedom to change roles in order to achieve physical and emotional growth); 4.- Affection (how well can emotional experiences or satisfaction be shared by their emotional interaction); 5.- Resources or Capacity of Resolution (level of satisfaction with the time shared with family). According to the results, it determines if family functionality is normal, mildly, moderately, or severely dysfunctional. ${ }^{14}$ Hypoglycemia was classified as: mild $(70-55 \mathrm{mg} / \mathrm{dL})$, moderate $(54-31 \mathrm{mg} / \mathrm{dL})$ and severe $(<30$ $\mathrm{mg} / \mathrm{dL}) .{ }^{1}$ We collected the following information from each patient: age, gender, level of hypoglycemia, level of family functionality and FLC phase. The present study adheres to the guidelines in the Declaration of Helsinki and the local research committee of IMSS. Participation required patient agreement and signature of an informed written consent.

\section{Statistical analysis}

Descriptive statistics were used with measures of central tendency for quantitative variables, frequencies and percentages for qualitative variables and Chi-square test to determine the association between family functionality and hypoglycemia. The information was collected and analyzed with the statistical program SPSS version 21.

\section{Results}

The total number of patients with type 2 diabetes in the hospital registry amounted to 7,830. During the study period, a total of 167 $(2.13 \%)$ patients developed hypoglycemia. After applying the inclusion and exclusion criteria, a total of 160 (2.04\% of all diabetics) patients were included in the study. Gender wise, $60.6 \%(n=97)$ were female and $39.4 \%(n=63)$ were male. Patients were grouped by decades, and patients aged $61-70$ years $(36.25 \%)$ were the most frequent (Figure 1). According to the family APGAR questionnaire, mild family dysfunction was present in $52.5 \%$ of families. Regarding family life cycle, $33.8 \%$ of patients were going through the contraction phase (Table 1). After applying the Chi-squared test of independence, a statistically significant relationship between hypoglycemia and family functionality was determined (Chi-square 14.809, $\mathrm{p}=0.022$, Table 2). An association between hypoglycemia and family life cycle phase was also observed (Chi-square 18.028, $\mathrm{p}=0.021$, Table 3).

Table I Family functionality and life cycle

\begin{tabular}{lll}
\hline Family functionality & Frequency & Percentage \\
\hline Normal & 24 & 15 \\
Mild dysfunction & 84 & 52.5 \\
Moderate dysfunction & 51 & 31.9 \\
Severe dysfunction & 1 & 0.6 \\
Total & 160 & 100 \\
Family life cycle & & \\
Formation & 6 & 3.8 \\
Extension & 13 & 8.1 \\
Completed extension & 52 & 32.5 \\
Contraction & 54 & 33.8 \\
Completed contraction & 35 & 21.9 \\
Total & 160 & 100
\end{tabular}

Table 2 Relationship between hypoglycemia and family functionality

\begin{tabular}{|c|c|c|c|c|c|c|c|c|c|c|}
\hline \multirow[t]{3}{*}{ Hypoglycemia } & \multicolumn{10}{|c|}{ Family functionality } \\
\hline & \multicolumn{2}{|c|}{ Functional } & \multicolumn{2}{|c|}{ Mild dysfunction } & \multicolumn{2}{|c|}{ Moderate dysfunction } & \multicolumn{2}{|c|}{ Severe dysfunction } & \multicolumn{2}{|c|}{ Total } \\
\hline & $\mathbf{n}$ & $\%$ & $\mathbf{n}$ & $\%$ & $\mathbf{n}$ & $\%$ & $\mathbf{n}$ & $\%$ & $\mathbf{n}$ & $\%$ \\
\hline Mild & 12 & 50 & 43 & 51.2 & 11 & 21.6 & 0 & 0 & 66 & 41.3 \\
\hline Moderate & 12 & 50 & 36 & 42.9 & 37 & 72.5 & 1 & 100 & 86 & 53.8 \\
\hline Severe & 0 & 0 & 5 & 6 & 3 & 5.9 & 0 & 0 & 8 & 5 \\
\hline Total & 24 & 100 & 84 & 100 & 51 & 100 & 1 & 100 & 160 & 100 \\
\hline
\end{tabular}

$\mathrm{N}$, number of patients 
Table 3 Relationship between hypoglycemia and family life cycle

\begin{tabular}{|c|c|c|c|c|c|c|c|c|c|c|c|c|}
\hline \multirow[t]{3}{*}{ Hypoglycemia } & \multicolumn{12}{|c|}{ Family life cycle } \\
\hline & \multicolumn{2}{|c|}{ Formation } & \multicolumn{2}{|c|}{ Extension } & \multicolumn{2}{|c|}{$\begin{array}{l}\text { Completed } \\
\text { extension }\end{array}$} & \multicolumn{2}{|c|}{ Contraction } & \multicolumn{2}{|c|}{$\begin{array}{l}\text { Completed } \\
\text { contraction }\end{array}$} & \multicolumn{2}{|c|}{ Total } \\
\hline & $\mathbf{n}$ & $\%$ & $\mathbf{n}$ & $\%$ & $\mathbf{n}$ & $\%$ & $\mathbf{n}$ & $\%$ & $\mathbf{n}$ & $\%$ & $\mathbf{n}$ & $\%$ \\
\hline Mild & 2 & 33 & 9 & 69 & 26 & 50 & 22 & $4 I$ & 7 & 20 & 66 & 41.3 \\
\hline Moderate & 3 & 50 & 4 & 31 & 26 & 50 & 29 & 54 & 24 & 68.6 & 86 & 53.8 \\
\hline Severe & I & 17 & 0 & 0 & 0 & 0 & 3 & 5.6 & 4 & II.4 & 8 & 5 \\
\hline Total & 6 & 100 & 13 & 100 & 52 & 100 & 54 & 100 & 35 & 100 & 160 & 100 \\
\hline
\end{tabular}

$\mathrm{N}$, number of patients

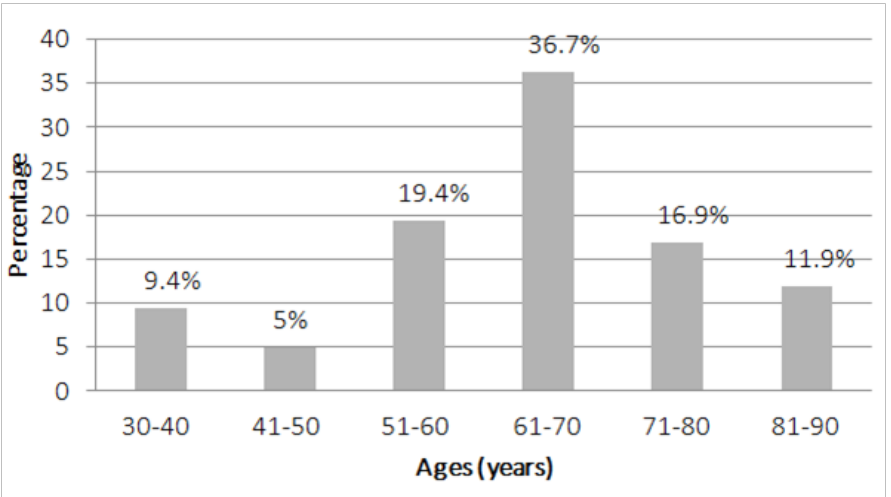

Figure I Patient distribution by age.

\section{Discussion}

The frequency of hypoglycemia $(2.13 \%)$ was lower than the $5.56 \%$ stated by Mexico's Epidemiological Surveillance System, ${ }^{15}$ yet lower than other similar studies, such as the one by Casanova et al. ${ }^{16}$ where they reported a frequency of $0.6 \%$. Prevalence oscillates between authors, ranging from $8.7 \%$ to $25.2 \%$; the vast difference among studies may be due to patient comorbidities and the level of attention provided by the hospitals in which they are conducted. ${ }^{17,18}$ Female gender and ages 61-70 years were the most common, similar to the studies carried out by Almanza et al.,, ${ }^{2,19}$ In relation to family functionality, $85 \%(n=136)$ of patients had some degree of dysfunction. Mild dysfunction was the most prevalent form of dysfunction, which parallels the conclusions made by Beltrán and Mar in their studies. ${ }^{11,20}$ Conversely, moderate dysfunction was predominant in the study by Lagos et al. ${ }^{21} \mathrm{~A}$ correlation between the family APGAR score and the general self-management has been documented in studies done in Peru and Mexico. ${ }^{21-23}$ An association between hypoglycemia and FLC was also proved in this study. The contraction stage was the most prevalent, being present in $33.7 \%$ of the families, similar to that found by Moreno, ${ }^{24}$ where it was $21.7 \%$. This predominance can be explained because the contraction stage is characterized by the departure of the children from home, which translates as lack of support, hence affecting the family. It has also been shown that greater social support is associated with better health outcomes and healthier behavior. A 2014 randomized control trial conducted in Iran, where family members in the intervention group were given lessons about the importance of medication adherence and family support behavior, found that there was a significant difference between the mean Diabetes Social Support Questionnaire-Family questionnaire score before and after the intervention. ${ }^{25}$ This shows that education programs can enable family members to be more supportive and in turn, create a better environment for the patient, to appropriately control their diabetes.

\section{Conclusion}

An association between family functionality and hypoglycemia in patients with type 2 diabetes exists. The patient's family environment should be taken into consideration in order to achieve metabolic control and prevent complications.

\section{Acknowledgments}

None.

\section{Conflicts of interest}

The author declares there is no conflict of interest.

\section{References}

1. American Diabetes Association. Hypoglycemia.

2. Almanza O, Chia E, De la Cruz A, et al. Frecuencia de factores asociados a hipoglucemia en el adulto mayor diabético admitido en el servicio de emergencia de un hospital nacional. Rev Med Hered. 2017;28(2).

3. Organización Panamericana de la Salud. Presentación Guías ALAD de diagnóstico, control y tratamiento de la Diabetes Mellitus Tipo 2. Washington DC; CPS. 2012. p. 42-43.

4. Vírseda HJA, Bezanilla SJM. Enfermedad y familia. Volumen 1. 1st edn. México: UNAM; 2014. p.18-22.

5. Smilkstein G. The family APGAR: a proposal for a family function test and its use by physicians. J Fam Pract. 1978;6(6):1231-1239.

6. Bautista RM, Zambrano PGE. La calidad de vida percibida en pacientes diabéticos tipo 2. Investig Enferm Imag y Desarr. 2014;17(1):131-148.

7. Moratto VNS, Zapata PJJ, Messager T. Conceptualización del ciclo familiar: una mirada a la producción durante el periodo comprendido entre los años 2002 a 2015. Rev CES Psicología. 2015;8(2):103-121.

8. De la Villa AL, Fleitas CL. Enfoque familiar de los problemas psicosociales. Atención longitudinal: ciclo vital familiar, Martín Zurro A, Cano PJF. Atencion primaria conceptos, organización y práctica clínica. $5^{a}$ edn. España: Elsevier, 2003. p. 157-171. 
9. Torres RA, Morales CFA, Arriga MG, et al. Funcionalidad familiar desde la perspectiva de un integrante con diabetes mellitus tipo 2 en la sierra Negra de Puebla. J Health NPEPS. 2016;1(2):136-144.

10. La Greca AM, Bearman KJ. The diabetes social support questionnairefamily version: evaluating adolescents' diabetes-specific support from family members. J Pediatr Psychol. 2002;27(8):665-676.

11. Beltrán CP, Sola VJ, Quezada RA. Impacto de un club de Diabeticos sobre la glicemia, funcionalidad familiar y ansiedad. Hospital Moreno Vázquez; Gualaceo. Rev Med HJCA. 2015;7(2):150-154.

12. González TWA. Conocimiento sobre diabetes mellitus tipo 2 y funcionalidad familiar asociados a la adherencia terapéutica en diabeticos tipo 2, Hospital Militar Central. Lima, noviembre 2014-enero 2015. Universidad Mayor de San Marcos. Lima; 2015. p. 45-51.

13. Castilla $\mathrm{CH}$, Caycho RT, Ventura LJ, et al. Análisis factorial confirmatorio de la escala de percepción del funcionamiento familiar de Smilkstein en adolescentes peruanos. Salud \& Sociedad. 2015;6(2):140-153.

14. Suarez CMA, Alcalá EM. APGAR Familiar: una herramienta para detectar disfunción familiar. Rev Méd La Paz. 2014;20(1):1-6.

15. Dirección General de Epidemiología. Boletín Epidemiológico Diabetes Mellitus Tipo 2 cierre 2016. Sistema de Vigilancia Epidemiológica Hospitalaria de Diabetes Mellitus tipo 2. Secretaría de Salud. 2017.

16. Casanova CLJ, Montero BMO, Yarza FJ, et al. Hipoglucemia grave en pacientes con diabetes mellitus 2 y azoados normales. Rev Med int Mex. 2017;33(6):739-745.

17. Ticse R, Chávez D, Valenzuela F, et al. Frecuencia y factores asociados a la hipoglucemia en pacientes con diabetes mellitus tipo 2 hospitalizados. Rev Soc Peru Med Interna. 2014;27(4):171-176.
18. Iniesta NC, Vera PL, Rentero RL. Hipoglucemia: prevalencia y factores asociados en el paciente anciano hospitalizado. Hospital General Universitario Reina Sofía, Murcia. Endocrinol Nutr. 2016;63(10):168.

19. Rivera TA, Álvarez VT, Ochoa JF. Comportamiento de hemoglobina glicosilada y frecuencia de hipoglucemia en diabéticos tipo 2 con insulina glagina o NPH. Rev Med Risalba. 2016;22(1):3-10.

20. Mar G, Peñarrieta DC, León H, et al. Relación entre automanejo y percepción de funcionalidad familiar en personas con diabetes mellitus tipo 2. Rev Enferm Univ. 2017;14(3):155-161.

21. Lagos MH, Flores RN. Funcionalidad familiar y automanejo en pacientes con diabetes mellitus e hipertensión arterial en el Hospital de Puente Piedra-Lima. Rev Cuid Salud. 2014;1(2):85-92.

22. García J, Peñarrieta I, León R, Gutiérrez T, Banda O, Rangel S, et al. Relación entre automanejo y percepción de funcionalidad familiar en personas con diabetes mellitus tipo 2. Enfermería Universitaria. 2017;14(3):155-161.

23. Peñarrieta MI, Flores F, Gutiérrez T, et al. Self-management and family support in chronic diseases. J Nurs Educ Pract. 2015;5(11):73-80.

24. Moreno AJA. Ciclo vital familiar y estilo de vida, en pacientes con diabetes mellitus tipo 2, de la unidad de medicina familiar número 64, del Instituto Mexicano del Seguro Social en el periodo del 2011 al 2012. Universidad Autónoma del Estado de México; 2013. p. 1-84.

25. Khosravizade $H$, Madarshahian F, Khoshniat M, et al. Impact of family support improvement behaviors on anti diabetic medication adherence and cognition in type 2 diabetic patients. J Diabetes Metab Disord. 2014;13(1):113. 